
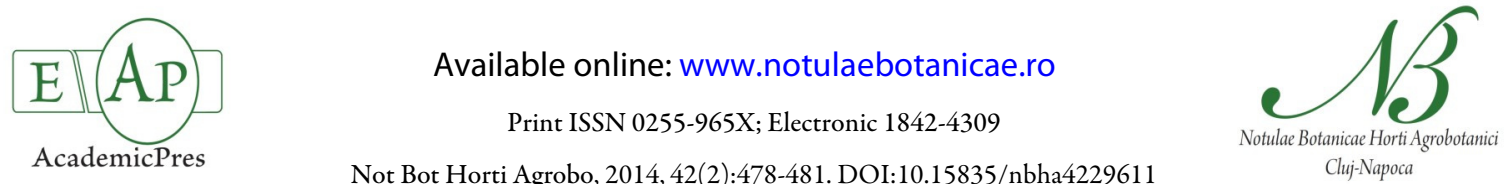

\title{
Cutting Type and IBA Treatment Duration Affect Teucrium fruticans Adventitious Root Quality
}

\author{
Leo SABATINO, Fabio D’ANNA, Giovanni IAPICHINO*
}

University of Palermo, Department of Agricultural and Forest Sciences, Viale delle Scienze, 90128, Palermo, Italy; leo.sabatino@unipa.it;

fabio.danna@unipa.it; giovanni.iapichino@unipa.it(*correspondingauthor)

\begin{abstract}
Root development of stem cuttings of Silver Germander (Teucrium fruticans) was investigated in relation to cutting type and indole-3-butyric acid (IBA) treatment. Terminal cuttings of a clone grown in Sicily were trimmed to three types: terminal cuttings with apex (TWA), terminal cuttings without apex (TWOA) or sub-terminal cuttings (ST). To verify the cutting response to exogenous auxin, cuttings were dipped to a $2.0 \mathrm{~cm}$ depth in a $0.5 \%$ indole-3-butyric acid solution for 0,5 or 7 minutes. Overall percent survival was 97 to $98 \%$. Rooting percent, root number and root length were affected by cutting type and indole-3-butyric acid treatment. In general, TWA cuttings demonstrated a higher capacity to form roots than cuttings without apex (TWOA and ST cuttings). In absence of indole-3-butyric acid treatment, TWA and ST cuttings gave higher rooting percentages than TWOA cuttings. Exposing cuttings to indole-3-butyric acid improved percent rooting, number of roots per cutting and root length. The best results in terms of rooting percentage and root number per cuttings were obtained with TWA cuttings in combination with $7 \mathrm{~min}$ indole-3-butyric acid basal dip. However, cuttings taken farther down the stem, such as sub-terminal cuttings gave satisfactory rooting performance as well. We suggest that the use of all cutting types tested associated to indole-3-butyric acid basal dip for 5 or 7 min may be beneficial to propagators wishing to produce $T$. fruticans rooted cuttings with well-developed root system.
\end{abstract}

Keywords: basal dip, growth regulators, Labiatae, native plants, rooting

\section{Introduction}

The genus Teucrium belongs to the family Labiatae and contains more than 300 perennial herbs, shrubs and subshrubs mainly native to Mediterranean region and southwestern Asia (Bryant, 2003). Teucrium fruticans, also known as Silver Germander, is a shrub native to Southern Europe and North Africa (Graham, 1992). Cultivated for its attractive blue/violet flowers and evergreen foliage, graygreen above and silver-white beneath, T. fruticans is high drought tolerant and suitable for landscaping in areas with Mediterranean-type environment (Cassaniti et al., 2009; La Mantia et al., 2012; Lopez et al., 2006). Four-year old plants (sold in 22-cm-diameter pots) obtained by rooted cuttings are generally used for landscaping. Teucrium fruticans propagation by seed is difficult because of poor germination (Bryant, 2003) and high percentage of male sterility (Ojeda and Diez, 1992); as a result, plant propagation via seed is unsatisfactory for the commercial production (Frabetti et al., 2009). The species has been also characterized as difficult to propagate by cutting in certain periods of the year (Frangi and Nicola, 2004). To circumvent these problems micropropagation has been recommended (Frabetti et al., 2009). Vegetative propagation by stem cuttings has been successfully applied to other Teucrium species ( $T$. divaricatum, $T$. polium, $T$. chamaedrys, $T$. flavum, T. scorodomia) (Dirr and Heuser, 2006; Iapichino et al., 2006; MacDonald, 1987; Maloupa et al., 2008). Although the effects of exogenous auxin on adventitious root formation in Teucrium species has been documented (Dirr and Heuser 1987; Frangi and Nicola 2004; Maloupa et al., 2008) no research on the influence of the morphological characteristics of the cuttings on rooting of $T$. fruticans has been reported. The aim of our study was to examine rooting of stem cuttings in relation to cutting type and IBA treatment duration in a $T$. fruticans clone grown in Sicily.

\section{Materials and methods}

\section{Plant material}

The research was conducted at the University of Palermo, Experimental Station in the Northern coast of Sicily (Italy) (longitude $13^{\circ} 19^{\prime} \mathrm{E}$, latitude $38^{\circ} 9^{\prime} \mathrm{N}$ ). Terminal $30 \mathrm{~cm}$ long stem cuttings were harvested on 23 April 2012 from actively growing stock plants. Plants were 5 years old and from a single Sicilian unnamed clone. Cuttings were stored overnight at $6^{\circ} \mathrm{C}$. The next day, the cuttings were trimmed to three types: 
479

softwood stem-tip cuttings in which the tip was retained (terminal cuttings with apex, TWA), softwood stem cuttings in which the tip was removed (terminal cuttings without apex, TWOA) or semi-hardwood cuttings taken farther down the stem (sub-terminal cuttings, ST) (Fig. 1).

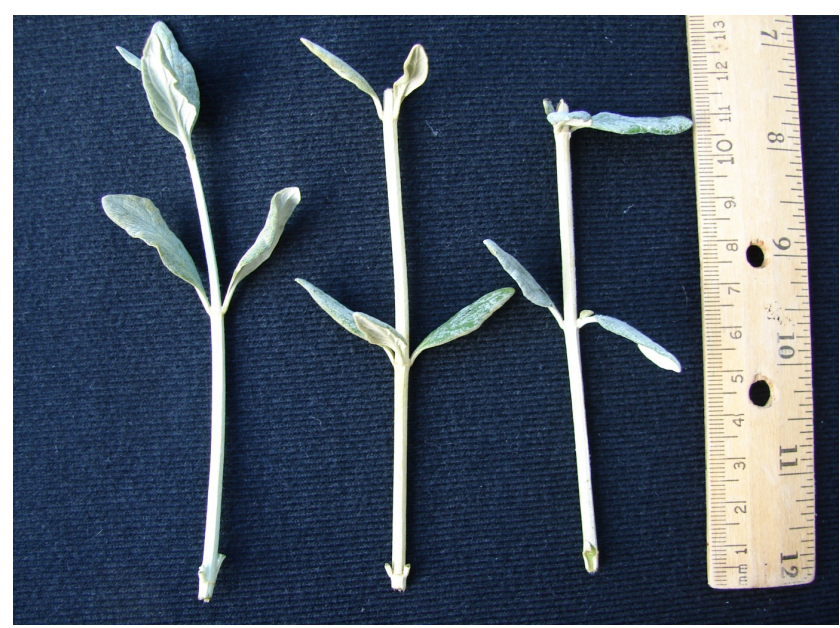

Fig. 1. Teucrium frutescens cutting types tested; from left, terminal with apex, terminal without apex and sub-terminal

All cuttings were trinodal with the lower cut below a node at the base of each cutting. Leaves were removed from the base of the stem; length and diameter of the cuttings were $12-14 \mathrm{~cm}$ and $0.4 \mathrm{~cm}$, respectively.

\section{Auxin treatment}

To verify the cutting response to exogenous auxin, cuttings were dipped to a $2.0 \mathrm{~cm}$ depth in a $0.5 \%$ indole-3-butyric acid (IBA) solution (Frangi and Nicola, 2004) for five or seven minutes. Reagent grade IBA (Sigma n. I 5386) was dissolved in $90 \%$ ethanol, then brought to final concentration of $6 \%$ ethanol $94 \%$ distilled water $(\mathrm{v} / \mathrm{v})$. Untreated cuttings were dipped in distilled water (control $=0$ minutes).

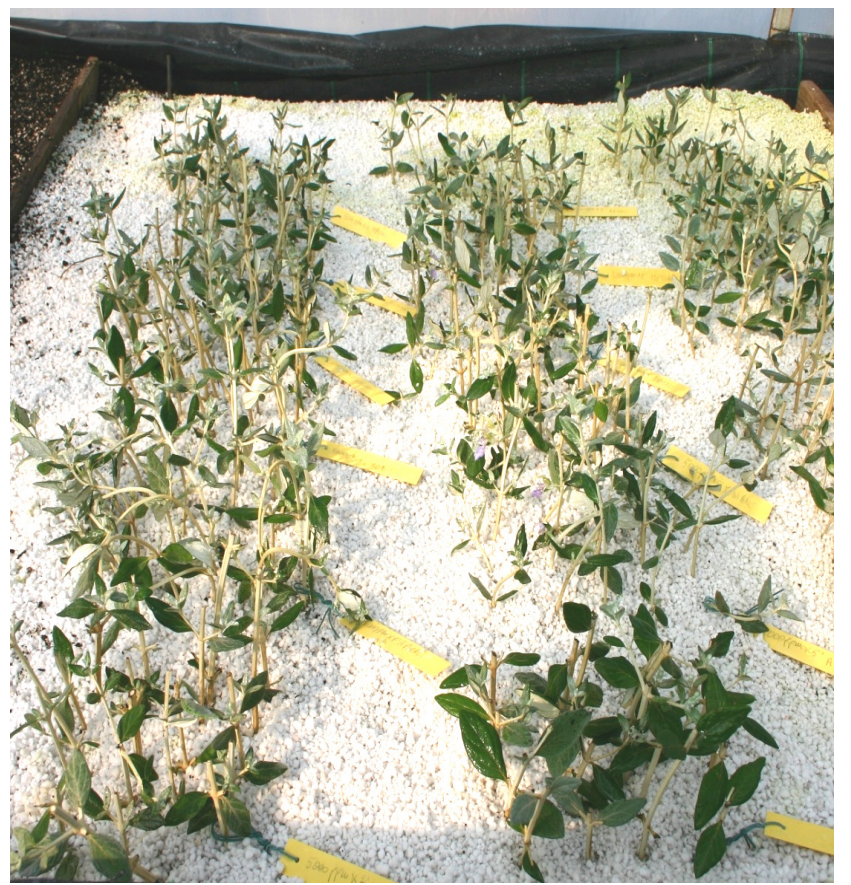

Fig. 2. Teucrium frutescens cuttings in the rooting bench

\section{Rooting conditions}

Propagation was performed on 24 April 2012 in an unheated greenhouse covered with clear polyethylene (PE) and external $50 \%$ shade-cloth. Air temperature in the greenhouse was $18-22{ }^{\circ} \mathrm{C}$ during the day and $14-16{ }^{\circ} \mathrm{C}$ during the night. Cuttings were inserted $4 \mathrm{~cm}$ deep in a bottom heated bench containing perlite. Basal heat was provided at constant temperature of $25 \pm 2{ }^{\circ} \mathrm{C}$. Benches were covered with clear PE to maintain high relative humidity. Intermittent mist operated daily $30 \mathrm{sec}$ every 2 hours from 8:30 AM to 6:00 PM. Ventilation of the cuttings was increased with time by increasing size of the holes made in the plastic.

\section{Experimental design, data collection and analysis}

The design was a randomized complete block (RCB) with three replications, nine treatments [three cutting types $\mathrm{x}$ three IBA exposure time duration (0,5 or 7 minutes)] and 20 cuttings per replication. An IBA cutting exposition of a few seconds (quick dip method) was not included in our experimental design because in a preliminary experiment (performed in the same season) we did not find any significant increase in rooting capacity as compared to the untreated control. After 4 and 6 weeks, cuttings were evaluated for percent survival, percent rooting, number of roots, length of the six longest roots. Cuttings with non-withered stems (with and without roots) were considered to have survived. Cuttings with necrotic tissue without roots were classified as dead. Percentage data were subjected to arcsin transformation before ANOVA analysis. Mean separation was performed by Fisher leastsignificant-difference test at $p \leq 0.01$ (Petersen, 1985).

\section{Plant establishment}

Single plants were transferred to each plastic pot (diameter $16 \mathrm{~cm}$ ) containing a peat-perlite mixture 1:1 (v/v) and kept for five weeks in a lath house covered with $70 \%$ shade-cloth. Acclimatized plants were thereafter transferred in the open field.

The experiment was repeated a second year using the same stock plants and obtaining similar results.

\section{Results}

\section{Cutting survival and rooting percentage}

Overall percent survival was 97 to $98 \%$; no significant effect of cutting type and IBA treatment duration was found on cutting survival (Tab. 1). Rooting percent was affected by cutting type and IBA treatment (Tab. 1). In absence of IBA treatment, TWA and ST cuttings gave higher rooting percentages than TWOA cuttings. Percent rooting in TWA cuttings increased from $70 \%$ in absence of IBA treatment to 100 and $96 \%$ in the presence of IBA for 5 and $7 \mathrm{~min}$, respectively; percent rooting in TWOA cuttings also increased from $56 \%$ in untreated control to $100 \%$ in cuttings receiving either 5 or $7 \mathrm{~min}$ IBA basal dips. Percent data recorded on ST cuttings paralleled data recorded on TWA and TWOA cuttings exposed to IBA giving higher performance than control.

\section{Root number}

The number of roots was affected by cutting type and IBA treatment. In general, TWA cuttings demonstrated a 
higher capacity to form roots than cuttings without apex (TWOA and ST cuttings). Exposing cuttings to IBA improved the number of roots per cutting (Fig. 2). Data collected 4 weeks after planting revealed that formed roots on TWA cuttings increased from 1.0 in untreated control to 14 and 18 roots on stem cuttings receiving 5 and $7 \mathrm{~min}$
IBA basal dips, respectively. Root count in TWOA cuttings also increased from 1.5 roots in absence of IBA to 11 roots at 5 min duration and to 20 roots at $7 \mathrm{~min}$ duration. Data collected on ST cuttings supported the trend established for the other two cutting types with a maximum of 13 roots for the cuttings receiving $7 \mathrm{~min}$ IBA basal dip. Data collected

Tab. 1. Effects of cutting type and IBA treatment on Teucrium fruticans rooting

\begin{tabular}{|c|c|c|c|c|c|c|c|}
\hline \multicolumn{2}{|c|}{ Treatments } & \multicolumn{2}{|c|}{ Roots per cutting (n) } & \multirow{2}{*}{\multicolumn{2}{|c|}{$\begin{array}{c}\text { Root length }(\mathrm{mm}) \\
\text { Weeks after planting }\end{array}$}} & \multirow{3}{*}{$\begin{array}{c}\text { Rooting }(\%) \\
6\end{array}$} & \multirow{3}{*}{$\begin{array}{c}\text { Survival (\%) } \\
6\end{array}$} \\
\hline \multirow{2}{*}{ Cutting type } & \multirow{2}{*}{$\begin{array}{c}\text { IBA } \\
(\min .)\end{array}$} & & & & & & \\
\hline & & 4 & 6 & 4 & 6 & & \\
\hline TWA & 0 & $1.0 \pm 0.8 \mathrm{e}$ & $11.4 \pm 4.2 \mathrm{~d}$ & $3.5 \pm 1.6 \mathrm{de}$ & $6.8 \pm 2.5 \mathrm{e}$ & $70 \pm 0.3 \mathrm{~d}$ & $97.0 \pm 1.3 \mathrm{a}$ \\
\hline TWA & 5 & $14.7 \pm 3.8 \mathrm{~b}$ & $18.4 \pm 3.9 \mathrm{bc}$ & $5.9 \pm 0.5 \mathrm{ab}$ & $10.1 \pm 3.9 \mathrm{abc}$ & $100 \mathrm{a}$ & $98.0 \pm 2.8 \mathrm{a}$ \\
\hline TWA & 7 & $18.5 \pm 3.3 \mathrm{a}$ & $24.0 \pm 3.6 \mathrm{a}$ & $4.7 \pm 1.8 \mathrm{bcd}$ & $11.5 \pm 4.1 \mathrm{a}$ & $96 \pm 2.8 \mathrm{ab}$ & $97.1 \pm 2.5 \mathrm{a}$ \\
\hline TWOA & 0 & $1.5 \pm 0.7 \mathrm{e}$ & $4.0 \pm 2.4 \mathrm{e}$ & $2.5 \pm 0.8 \mathrm{e}$ & $5.3 \pm 2.8 \mathrm{f}$ & $56 \pm 2.1 \mathrm{e}$ & $98.0 \pm 2.1 \mathrm{a}$ \\
\hline TWOA & 5 & $11.0 \pm 4.2 \mathrm{~cd}$ & $14.3 \pm 2.5 \mathrm{~d}$ & $7.0 \pm 1.0 \mathrm{a}$ & $10.5 \pm 4.1 \mathrm{ab}$ & $100 \mathrm{a}$ & $98.0 \pm 1.8 \mathrm{a}$ \\
\hline TWOA & 7 & $20.1 \pm 1.5 \mathrm{a}$ & $20.2 \pm 2.1 \mathrm{ab}$ & $5.0 \pm 2.1 \mathrm{abc}$ & $9.3 \pm 2.1 \mathrm{bcd}$ & $100 \mathrm{a}$ & $97.6 \pm 2.8 \mathrm{a}$ \\
\hline ST & 0 & $1.9 \pm 0.6 \mathrm{e}$ & $6.1 \pm 2.6 \mathrm{e}$ & $2.6 \pm 1.2 \mathrm{e}$ & $5.0 \pm 2.7 \mathrm{f}$ & $81 \pm 3.4 \mathrm{~cd}$ & $98.0 \pm 3.6 \mathrm{a}$ \\
\hline ST & 5 & $9.7 \pm 2.9 \mathrm{~d}$ & $13.1 \pm 4.7 \mathrm{~d}$ & $3.2 \pm 0.9 \mathrm{de}$ & $7.8 \pm 3.2 \mathrm{e}$ & $100 \mathrm{a}$ & $98.0 \pm 2.0 \mathrm{a}$ \\
\hline ST & 7 & $13.0 \pm 1.8 \mathrm{bc}$ & $15.0 \pm 2.2 \mathrm{~d}$ & $4.2 \pm 1.6 \mathrm{~cd}$ & $7.7 \pm 3.1 \mathrm{e}$ & $92 \pm 1.7 \mathrm{abc}$ & $97.6 \pm 2.5 \mathrm{a}$ \\
\hline
\end{tabular}

Values represent mean \pm standard error. In each column, means followed by the same letters are not significantly different at the $p \leq 0.01 \%$ level by Fisher's protected least significant difference test.

TWA = terminal cuttings with apex; TWOA = terminal cuttings without apex; ST = sub-terminal cuttings.

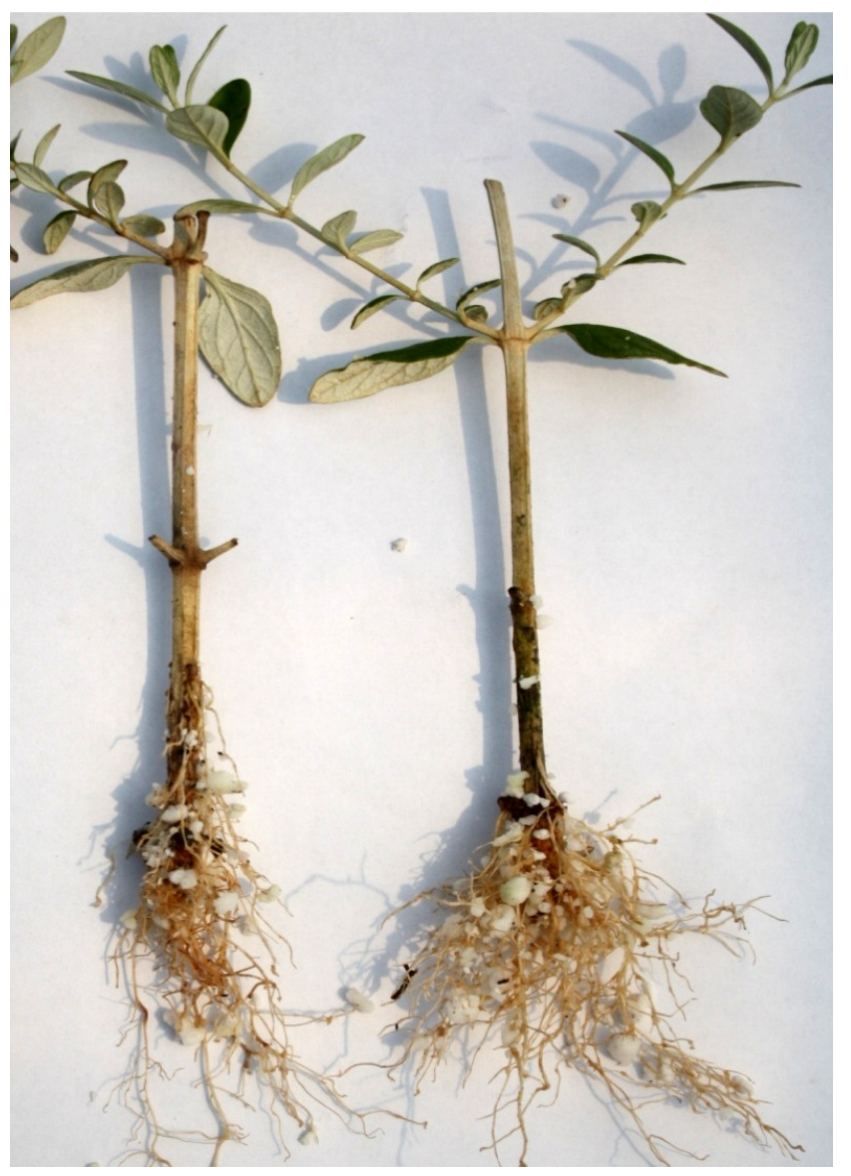

Fig. 3. Teucrium frutescens sub-terminal cuttings, exposed to 7 min IBA basal dip, showing a well developed rooting system after 6 weeks again revealed that rooting TWA, TWOA and ST cuttings in the presence of IBA substantially increased the number of roots per cutting as compared to untreated cuttings. All cutting types generally produced higher number of roots per cutting with $7 \mathrm{~min}$ IBA basal dip as compared with 5 min IBA basal dip. Among the treatments tested, TWA cuttings in combination with 7 min IBA basal dip was the most effective in terms of number of adventitious roots produced.

\section{Root length}

Root length also varied by cutting type and IBA treatment. Generally, TWA cuttings formed longer roots than cuttings without apex (TWOA and ST cuttings). Data collected four and six weeks after planting, revealed that root length increased from the untreated control to stem cuttings receiving IBA basal dips. However, no significant differences were found between 5 and $7 \mathrm{~min}$ IBA basal dip.

\section{Plant establishment and performance}

In the present study, propagated plants grew vigorously, were morphological normal and began to flower during spring 2013.

\section{Discussion}

Our results are similar to those of Krisantini $e t$ al. (2003) who report tip cuttings having a higher capacity to form roots than decapitated cuttings in Grevillea and are consistent with those of Marks (1996) who found inhibition of rooting following tip removal in Quercus and Daphne cuttings. The higher rooting percentage obtained using tip cuttings rather than stem (decapitated) cuttings 
481

has been hypothesized as due to production of a factor (presumably, IAA basipetally transferred from the meristems) that from the apex has an important role in adventitious root formation even though exogenous auxin is applied. In our study, the slightly higher, but not statistically different percentage rooting observed in ST cuttings as compared to TWA cuttings could be attributed to the fact that IAA was supplied from quiescent axillary buds. However, our study also demonstrated that the number of roots formed in cuttings with apices was superior to that observed in those without apices even in the presence of exogenous auxin.

In our study, the application of IBA improved rooting percentage and root number as compared to untreated control. IBA has been reported to markedly increase adventitious root formation in many species (Blazich, 1988; De Klerk et al., 1999; Hartmann et al., 1997). Our results are only partially in agreement with those obtained by Frangi and Nicola et al. (2004) who found IBA treatments enhancing rooting in T. fruticans stem tip cuttings. These authors report a low rooting response during spring ( $40 \%$ rooting) even applying exogenous auxin. Our higher response in the same season could be related to diverse genotype studied or different environmental conditions under which the stock plants were grown. Our results are in accord with the results obtained by Carpenter and Cornell (1992) who, investigating the adventitious root proliferation response of three Hibiscus rosa-sinensis cultivars, found that rooting is highly influenced by IBA application duration and concentration. Our results are also consistent with those of Telgen et al. (2007) who reported that diluted IBA-solutions and longer dipping times resulted in more uniform cuttings and higher root number than quick dips in Rosa hybrida 'First Red'.

In the present study, the best results in terms of rooting percentage and root number per cuttings were obtained with TWA cuttings. However, this propagation method yields fewer cuttings per plant compared with methods using cuttings taken farther down the stem, such as subterminal cuttings which, in our study, also performed well. Therefore, we suggest that all cutting types tested and exposed to an IBA basal dip of 5 or 7 min may be successfully used by propagators to produce $T$. fruticans rooted cuttings with well-developed root system.

This is an important information for nursery growers since there is little knowledge about cultural techniques of this species of increasing importance in the landscape and nursery trade.

\section{References}

Blazich FA (1988). Chemicals and formulations used to promote adventitious rooting, p.132-149. In: Davis TD, Haissig BE, Sankhla N (Eds.). Adventitious root formation in cuttings. Dioscorides Press, Portland, Oregon.

Bryant G (2003). Plant propagation A to Z. Firefly Books (U.S.) Inc. Buffalo, New York, $224 \mathrm{pp}$.

Carpenter WJ, Cornell JA (1992). Auxin application duration and concentration govern rooting of Hibiscus stem cuttings. J Amer Soc Hort Sci 117:68-74.
Cassaniti C, Li Rosi A, Romano D (2009). Salt tolerance of ornamental shrubs mainly used in the Mediterranean landscape. Acta Hort 807:675-680.

De Klerk GJ (1999). The formation of adventitious roots: new concepts, new possibilities. In Vitro Cell Dev Biol Plant 35:189-199.

Dirr MA, Heuser CW (2006). The reference manual of woody plant propagation. Varsity Press, Athens, $410 \mathrm{pp}$.

Frabetti M, Gutiérrez-Pesce P, Mendoza de-Gyves E, Rugini E (2009). Micropropagation of Teucrium fruticans L., an ornamental and medicinal plant. In Vitro Cell Dev Biol Plant 45:129-134.

Frangi P, Nicola $S$ (2004). Study of propagation by cuttings of Mediterranean native species with ornamental potential (in Italian). Italus Hortus 4:191-193.

Graham ST (1992). Ornamental shrubs, climbers and bamboos. Sagapress, Inc./Timber Press, Inc, Portland, Oregon, 583 pp.

Hartmann HD, Kester DE, Davies FJ, Geneve RL (1997). Plant propagation: principles and practices. Prentice Hall, New Jersey, 770 pp.

Iapichino G, Amico Roxas U, Bertolino M, Accardo Palumbo S, Moncada A (2006). Propagation techniques for three Mediterranean native shrubs with potential as ornamental outdoor plants. Acta Hort 723:433-436.

Krisantini S, Johnston M, Williams RR, Beveridge C (2003). Propagation of Grevillea. Comb Proc Inter Plant Prop Soc 53:154-158.

La Mantia T, Messana G, Billeci V, Dimarca A, Del Signore M, Leanza M, Livreri S, Console G, Maraventano G, Nicolini G, Prazzi E, Quatrini P, Sanguedolce F, Sorrentino G, Pasta S. (2012). Combining bioengineering and plant conservation on a Mediterranean islet. iForest-Biogeosciences 12:296-305.

Lopez J, Gonzalez A, Fernandez JA, Banon S (2006). Ornamental use of Labiates for xeriscape in Mediterranean area. Acta Hort 723:459-464.

MacDonald B (1987). Introducing new and recommended plants into the nursery industry of British Columbia. Comb Proc Inter Plant Prop Soc 37:336-343.

Maloupa E, Grigoriadou K, Papanastassi K, Krigas N (2008). Conservation, propagation, development and utilization of xerophytic species of the native greek flora towards commercial floriculture. Acta Hort 766:205-214.

Marks TR (1996). The role of the shoot apex in controlling rhizogenesis in vitro. Plant Growth Reg 20:57-60.

Ojeda F, Diez MJ (1992). Pollen dimorphism in three Teucrium species (Lamiaceae). Plant Syst Evolution 183:43-49.

Petersen RG (1985). Design and analysis of experiments. Marcell Dekker, New York, 429 pp.

Telgen HJ van, Eveleens B, Garcia N (2007). Improving rooting uniformity in rose cuttings. Propagation of Ornamental Plants 4:190-194. 